\title{
ISOELECTRIC FOCUSING OF VITAMIN D BINDING PROTEIN (Gc): GENETIC DIVERSITY IN THE POPULATIONS OF IRAN
}

\author{
S.S. Papiha, ${ }^{1}$ I. White, ${ }^{1}$ M.T. Akbari, ${ }^{1}$ \\ and D.D. FARHUD ${ }^{2}$ \\ ${ }^{1}$ Department of Human Genetics, University of Newcastle upon Tyne, U.K. \\ ${ }^{2}$ School of Public Health, University of Tehran, Iran
}

\begin{abstract}
Summary Plasma samples from 678 individuals belonging to four ethnic groups of Iran were examined by thin layer polyacrylamide isoelectric focusing and the results were analyzed for inter- and intra-ethnic variation. The distribution of Ge alleles showed a wide range in the country but the intra-ethnic variation indicated only a moderate differentiation, already having occurred in two local religious groups. Overall the frequencies in Iranian populations fit well with those generally expected in the region of contact and an overlap of European and Asian populations.
\end{abstract}

The group-specific component (Gc) or vitamin D binding protein (VDBP) is one of the major polymorphic systems of the $\alpha_{1}$-globulin region of human plasma. Since the original work on Gc polymorphism (Hirschfeld, 1959), the genetic variation of the human Gc system has been extensively studied by immunoelectrophoresis and traditional electrophoresis using starch and polyacrylamide as supporting media (Bearn et al., 1964; Kitchin, 1965). Constans and Viau (1977) using polyacrylamide isoelectric focusing (PAIEF), followed by immunofixation with nonspecific antisera, described further genetically controlled microheterogeneity in the Gc system. The $G c^{*} I$ allele was shown to consist of two suballeles $G c^{*} I S$ and $G c^{*} I F$, thus giving three common alleles $\left(G c^{*} 2, G c^{*} 1 S\right.$ and $\left.G c^{*} 1 F\right)$ instead of the conventional two $\left(G c^{*} I\right.$ and $\left.G c^{*}\right)$. More than 82 rare alleles have also been described by conventional IEF and by an improved method of IEF using polyacrylamide gels containing $3 \mathrm{~m}$ urea (Constans et al., 1983). The frequencies of the $G c^{*} 1 S$ and $G c^{*} l F$ suballeles in populations of various racial origins and the localisation of some rare variants in certain regions and ethnic groups suggest that $\mathrm{Gc}$ is a useful marker for human taxonomic studies (Papiha et al., 1982a; Novo and Cleve, 1983).

The suballeles of the Gc system have added new dimensions to the study of population diversity (Papiha et al., 1983), but data on subtype variation are still limited to only a few populations of the world (Papiha et al., 1985). For Iran, apart

Received February 12, 1985 
from a single study of Zoroastrians (Papiha et al., 1982b), there is no examination of subtype heterogeneity among the large number of ethnic groups who inhabit the Iranian Plateau. The present investigation therefore describes the frequency distribution of $\mathrm{Gc}$ subtypes in four ethnic groups distinct morphologically and in religion.

\section{SUBJECTS AND METHODS}

Bandaris. Morphologically the Bandaris, who inhabit the southern coastal province, appear to be negroid. Ethnically and linguistically they represent admixture of Portuguese and Arabs with negroes brought into the region in the 15th century.

Turkomans. Morphologically the Turkomans, of the northern part of Iran, resemble Mongols and historically they are descendants of the Oghoz tribe who mixed with the indigenous settled and nomadic peoples.

Assyrians. Assyrians are a group of Christians, also known as Nestorians, with a long history in the middle east, and there is evidence that their ancestors contributed to the Mesopotamian civilisations. As a result of the movements of Assyrians in the early part of this century, several groups of them live today at several centres in Iran.

Armenians. The Armenians, who accepted Christianity early in 301AD and had considerable contact with European civilisation, once occupied a large part of the area now known as Turkey. In 1604 Shah Abbas brought them to Iran as captives.

As part of ongoing investigations on the structure of Iranian populations in this Department (Akbari et al., 1984, 1985) blood specimens from 162 Bandari from Bander Abbas; 63 Turkoman from Bander Turkoman; 272 Armenians from Uromia, Tabriz, Tehran and Isfahan; and 181 Assyrians from Tehran and Uromia, were tested for Gc subtypes according to slightly modified techniques previously described (Papiha et al., 1983). In brief, the method is as follows.

Isoelectric focusing was carried out on an LKB 2117 Multiphor system. The gels $0.25 \mathrm{~mm}$ thick were cast in glass moulds $260 \times 120 \times 1.5 \mathrm{~mm}$. The polyacrylamide solution contained $15 \mathrm{ml}$ of stock $(10 \%$ acrylamide, $0.3 \%$ bis-acrylamide cleared from free acrylic acid by $1 \mathrm{~g}$ amberlyte), $3.8 \mathrm{ml}$ glycerol, $1.6 \mathrm{ml}$ of ampholyte pH 4-6, $10.6 \mathrm{ml}$ distilled $\mathrm{H}_{2} \mathrm{O}$ and $1.1 \mathrm{~g}$ of MOPS (BDH). The solution was polymerised after de-gassing with $0.6 \mathrm{ml}$ of $1 \%$ solution of ammonium persulphate. Isoelectric focusing was performed for one and a half hours at maxima of $25 \mathrm{~W}$, $20 \mathrm{~mA}$ and 1,800 volts setting on an LKB 2197 power supply. Gc staining was performed by immunofixation with nonspecific Gc antisera as described by Constans and Viau (1977). 


\section{RESULTS AND DISCUSSION}

The observed and the expected numbers of Gc subtypes in the eight population samples are given in Table 1 , and the suballele frequencies calculated from these numbers are listed in Table 2. The phenotype distributions in all eight were in Hardy-Weinberg equilibrium.

Among the 678 individuals tested only the six common phenotypes were found in all the populations except the Turkomans who showed two additional rare phenotypes. Both these rare alleles were in heterozygotes combined with the common * IS allele. In one of the variants the mutant bands were anodal to the $1 \mathrm{~S}$ band and were positioned between the normal $1 \mathrm{~S}$ and $1 \mathrm{~F}$ bands, whereas in the other variant they were cathodal to the normal $1 \mathrm{~S}$ band. The exact characterisation of the variants is not yet possible.

For the $\mathrm{Gc}$ system there is no information on the variation in the populations of Iran, except the Zoroastrian. Kitchin and Bearn (1964), using traditional electrophoresis, provided Gc frequencies in Iranian Jews living in Israel. Bajatzadeh and Walter $(1968,1969)$ provided Gc frequencies in Iranians born in different regions of Iran but living in Germany. These investigations gave a $G c^{*} 2$ allele

Table 1. Distribution of Gc subtypes in Iranian populations.

\begin{tabular}{|c|c|c|c|c|c|c|c|c|c|c|}
\hline Population & Location & $\begin{array}{c}\text { Number } \\
\text { tested }\end{array}$ & & IF & IF-1S & $1 \mathrm{~S}$ & $2-1 S$ & $2-1 F$ & 2 & $\chi^{2}$ \\
\hline 1. Bandari & $\begin{array}{l}\text { Bandar- } \\
\text { Abbas }\end{array}$ & 162 & $\begin{array}{l}\text { Obs. } \\
\text { Exp. }\end{array}$ & $\begin{array}{l}8 \\
7.8\end{array}$ & $\begin{array}{l}38 \\
39.4\end{array}$ & $\begin{array}{l}52 \\
50.0\end{array}$ & $\begin{array}{l}38 \\
40.6\end{array}$ & $\begin{array}{l}17 \\
16.0\end{array}$ & $\begin{array}{l}9 \\
8.2\end{array}$ & 0.44 \\
\hline 2. Turkoman & $\begin{array}{l}\text { Bandar- } \\
\text { Turkoman }\end{array}$ & $63^{a}$ & $\begin{array}{l}\text { Obs. } \\
\text { Exp. }\end{array}$ & $\begin{array}{l}1 \\
1.6\end{array}$ & $\begin{array}{c}9 \\
10.7\end{array}$ & $\begin{array}{l}19 \\
17.3\end{array}$ & $\begin{array}{l}18 \\
19.7\end{array}$ & $\begin{array}{l}9 \\
6.1\end{array}$ & $\begin{array}{l}5 \\
5.6\end{array}$ & 2.23 \\
\hline 3. Armenian & Uromia & 48 & $\begin{array}{l}\text { Obs. } \\
\text { Exp. }\end{array}$ & $\begin{array}{l}4 \\
2.8\end{array}$ & $\begin{array}{l}13 \\
13.7\end{array}$ & $\begin{array}{l}16 \\
16.9\end{array}$ & $\begin{array}{l}12 \\
9.5\end{array}$ & $\begin{array}{l}2 \\
3.8\end{array}$ & $\begin{array}{l}1 \\
1.3\end{array}$ & 1.63 \\
\hline 4. Armenian & Tabriz & 63 & $\begin{array}{l}\text { Obs. } \\
\text { Exp. }\end{array}$ & $\begin{array}{l}1 \\
2.5\end{array}$ & $\begin{array}{l}14 \\
14.9\end{array}$ & $\begin{array}{l}23 \\
22.3\end{array}$ & $\begin{array}{l}15 \\
15.5\end{array}$ & $\begin{array}{l}9 \\
5.1\end{array}$ & $\begin{array}{l}1 \\
2.7\end{array}$ & 0.95 \\
\hline 5. Armenian & Tehran & 83 & $\begin{array}{l}\text { Obs. } \\
\text { Exp. }\end{array}$ & $\begin{array}{l}1 \\
1.5\end{array}$ & $\begin{array}{l}13 \\
12.3\end{array}$ & $\begin{array}{l}25 \\
26.0\end{array}$ & $\begin{array}{l}30 \\
28.6\end{array}$ & $\begin{array}{l}7 \\
6.8\end{array}$ & $\begin{array}{l}7 \\
7.8\end{array}$ & 0.22 \\
\hline 6. Armenian & Isfahan & 78 & $\begin{array}{l}\text { Obs. } \\
\text { Exp. }\end{array}$ & $\begin{array}{l}1 \\
2.0\end{array}$ & $\begin{array}{l}19 \\
12.8\end{array}$ & $\begin{array}{l}17 \\
20.5\end{array}$ & $\begin{array}{l}27 \\
26.2\end{array}$ & $\begin{array}{l}4 \\
8.2\end{array}$ & $\begin{array}{l}10 \\
8.3\end{array}$ & 4.90 \\
\hline 7. Assyrian & Tehran & 81 & $\begin{array}{l}\text { Obs. } \\
\text { Exp. }\end{array}$ & $\begin{array}{l}2 \\
3.0\end{array}$ & $\begin{array}{l}22 \\
19.7\end{array}$ & $\begin{array}{l}31 \\
32.7\end{array}$ & $\begin{array}{l}19 \\
17.8\end{array}$ & $\begin{array}{l}5 \\
5.4\end{array}$ & $\begin{array}{l}2 \\
2.4\end{array}$ & 0.49 \\
\hline 8. Assyrian & Uromia & 100 & $\begin{array}{l}\text { Obs. } \\
\text { Exp. }\end{array}$ & $\begin{array}{l}3 \\
2.9\end{array}$ & $\begin{array}{l}26 \\
24.8\end{array}$ & $\begin{array}{l}54 \\
53.3\end{array}$ & $\begin{array}{l}12 \\
14.6\end{array}$ & $\begin{array}{l}2 \\
3.4\end{array}$ & $\begin{array}{l}3 \\
1.0\end{array}$ & 0.61 \\
\hline
\end{tabular}


Table 2. Gene frequencies of Gc suballeles in Iranian populations.

\begin{tabular}{lccc}
\hline Population & \multicolumn{3}{c}{ Allele } \\
& $I F$ & $1 S$ & 2 \\
\hline Bandari & 0.219 & 0.556 & 0.225 \\
Turkoman & 0.164 & 0.533 & 0.303 \\
Armenian-Uromia & 0.239 & 0.594 & 0.167 \\
Armenian-Tabriz & 0.198 & 0.595 & 0.207 \\
Armenian-Tehran & 0.133 & 0.560 & 0.307 \\
Armenian-Isfahan & 0.160 & 0.513 & 0.327 \\
Assyrian-Tehran & 0.191 & 0.636 & 0.173 \\
Assyrian-Uromia & 0.170 & 0.730 & 0.100 \\
\hline
\end{tabular}

frequency range in Iran from $23-41 \%$. The present data, however, show that in many Iramian populations such as Bandaris, Assyrians and certain groups of Armenians, the frequencies of the $G c^{*} 2$ allele are low, thus suggesting a much wider frequency range in that country $(10-41 \%)$. In the local populations of Armenians there seems a clinal increase of $G c^{2}$ allele frequency as one moves from the northwest (Uromia) to the central parts of Iran (Tehran and Isfahan), an increase at the expense of the $G c^{*} 1 F$ allele, though this heterogeneity in allele frequency is not significant $\left(\chi^{2}=12.99\right.$, d.f. 9, NS). In Iran the Assyrians show the highest frequency of $G c^{*} 1 S$ and the lowest of $G c^{*} 2$ alleles. Differences between the two local Assyrian populations are small $\left(\chi^{2}=6.68\right.$, d.f. 3, NS). Comparison of the two Christian communities, Assyrian against Armenian, shows significant heterogeneity $\left(\chi^{2}=15.80\right.$, d.f. $5, \mathrm{p}<0.01)$.

The distribution of Ge subtypes in Bandaris and Turkomans shows interesting differences compared to the populations of Negroid and Mongoloid origin already studied from different parts of the world (Papiha et al., 1985). The populations with Negroid and Mongoloid affinities show a very high frequency of the $G c^{*} I F$ allele (42-86\% and $36-71 \%$, respectively). Both Bandaris, who show morphological similarity to Negroid, and Turkoman, who clearly show Mongoloid features, have lower $G c^{*} I F$ allele frequencies which are similar to those in European, Middle East and Asian populations (21 and $16 \%$, respectively). This diminution is due to increase of both the $G c^{*} 2$ and $G c^{*} I S$ alleles in both Bandari and Turkoman populations.

The present study therefore indicates that for the Ge system there is a considerable range of $\mathrm{Gc}$ suballele frequencies among the various populations of Iran which show an overall significant heterogeneity $\left(\chi^{2}=53.01\right.$, d.f. $\left.21, p<0.001\right)$. The Gc system adds another variable to those in our previous study to differentiate the Armenians and Assyrians (Akbari et al., 1985), and to support the previous conclusion of the closed nature of these two Christian communities with moderate dif- 
ferentiation among their local groups. Overall, however, the frequencies in these Iranian populations fit well with those generally expected in this region of contact and overlap of European and Asian populations.

Acknowledgments The authors are grateful to Professor D.F. Roberts for his continuous support and guidance during this work.

\section{REFERENCES}

Akbari, M.T., Papiha, S.S., Roberts, D.F., and Farhud, D.D. 1884. Serogenetic investigations of two populations of Iran. Hum. Hered. 34: 371-377

Akbari, M.T., Papiha, S.S., Roberts, D.F., and Farhud, D.D. 1985. Genetic variation among Iranian Christian communities. Am. J. Hum. Genet. in press.

Bajatzadeh, M. and Walter, H. 1968. Serum protein polymorphisms in Iran. Humangenetik 6: 40-54.

Bajatzadeh, M. and Walter, H. 1969. Investigation on the distribution of blood and serum groups in Iran. Hum. Biol. 41: 401-415.

Bearn, A.G., Kitchin, F.D., and Bowman, B.H. 1964. Heterogeneity of the inherited group-specific component of human serum. J. Exp. Med. 120: 83-89

Constans, J. and Viau, M. 1977. Group-specific component evidence for two subtypes of the $\mathrm{Gc}^{1}$ gene. Science 198: 1070-1071

Constans, J., Cleve, H., Dykes, D., Fischer, M., Kirk, R.L., Papiha, S.S., Scheffran, W., Scherz, R., Thymann, M., and Weber, W. 1983. The polymorphism of vitamin D binding protein $(\mathrm{Gc})$ isoelectric fosucing in $3 \mathrm{~m}$ urea as an additional method for identification of genetic markers. Hum. Genet. 65: 176-180

Hirschfeld, J. 1959. Immune-electrophoretic demonstration of qualitative differences in human sera and their relation to haptoglobin. Acta Pathol. Microbiol. Scand. 47: 160-168

Kitchin, F.D. and Bearn, A.G. 1964. Distribution of serum group-specific component (Gc) subtypes in Afghanistan, Korean, Nigerian and Israeli populations. Nature (Lond.) 202: 827-828

Kitchin, F.D. 1965. Demonstration of the inherited serum group-specific protein by acrylamide electrophoresis. Proc. Roy. Soc. Exp. Biol. Med. 119: 153-1160

Novo, S. and Cleve, H. 1983. Gc subtypes in Middle East: Report of an Arab Moslem population from Israel. Am. J. Phys. Anthropol. 60: 49-52

Papiha, S.S., Roberts, D.F., White, I., Chahal, S.M.S., and Asefi, A.J. 1982a. Population genetics of group-specific component $(\mathrm{Gc})$ and phosphoglucomutase $\left(\mathrm{PGM}_{1}\right)$ studied by isoelectric focusing. Am. J. Phys. Anthropol. 59: 1-7

Papiha, S.S., Seyedna, Y., and Sunderland, E. 1982b. Phosphoglucomutase (PGM) and groupspecific component $(\mathrm{Gc})$ isoelectric focusing among Zoroastrians of Iran. Ann. Hum. Biol. 9: 571-574

Papiha, S.S., White, I., and Roberts, D.F. 1983. Some genetic implications of isoelectric focusing of human red cell phosphoglucomutase $\left(\mathrm{PGM}_{1}\right)$ and serum protein group specific component $(\mathrm{Gc})$ : genetic diversity in the populations of Himachal Pradesh, India. Hum. Genet. 63: 67-72

Papiha, S.S., Constans, J., White, I., and McGregor, I.A. 1985. Group-specific component (Gc) subtypes in Gambian and Transkeian populations; a description of a new variant. Ann. Hum. Biol. 12: $17-26$ 